\title{
M. Reynaert
}

\section{SEXUAL ABUSE OF CHILDREN AS A FORM OF POWER ABUSE AND ABUSE OF THE BODY}

\section{ABSTRACT}

This article investigates the relationship between sexual abuse, power and the body from a Catholic theological viewpoint. The article starts with the relationship between sexual abuse and power. It is argued that sexual abuse is always a form of power abuse. A second step examines the relation between sexual abuse and the body. We may not ignore the theme of the body when we speak about sexual abuse as a form of power abuse. The article also explores whether the body is a theme in recent (theological and popular) literature on sexual abuse. It discusses how the perception of the body has an impact on dealing with the body and potential sexual abuse. The article concludes with a search for an appropriate image of the body that may reduce the prevalence of sexual abuse.

\section{INTRODUCTION}

2010, the sexual abuse by the bishop of Bruges shocks Belgium. Suddenly, sexual abuse is also a reality in the Belgian Catholic Church. However, sexual abuse of children happens not only in the church or in pastoral relationships, but also within families where adults sexually abuse children. As a result of these sexual abuse scandals, pastoral theological literature increasingly focuses on the theme of sexual abuse. Some literature is general (pastoral) theological literature about sexual abuse (Kiessling 2011; Keenan 2012) and about sexual abuse within a church context (Deetman et al. 2011; Borgman \& Torfs et al. 2011; Ganzevoort et al. 2013); some literature focuses on how to deal with, and respond to sexual abuse within

Dr. M. Reynaert, Faculty of Theology and Religious Studies, KU Leuven, Belgium. E-mail: machteld.reynaert@theo.kuleuven.be. Dr. Reynaert obtained her PhD from the Faculty of Theology and Religious Studies, KU Leuven, Belgium. Her research was about power, children and pastoral theology. She works at the same university on a project about Catholic identity. 
a church context (Dokecki 2004; De bisschoppen en hogere oversten van België 2012; Scicluna et al. 2012), and other literature focuses more on the consequences of the sexual abuse for the religiosity and spirituality of the victims (Shooter 2012). This explosion of literature gives rise to a range of definitions of, and visions on sexual abuse. I am convinced that sexual abuse occurs in those relationships where there is a power difference. It is, therefore, important not to neglect the role of power in sexual abuse.

The first section of this article addresses the relationship between sexual abuse and power. In addition to power, it is also important to not neglect the body in a discussion of sexual abuse. The second section of this article pays attention to the relationship between sexual abuse and the body. Sexual abuse has, for example, an enormous impact on the body of the victim. And the perception of the body has an impact on dealing with the body and potential sexual abuse. Certain images of the body are more likely to encourage sexual abuse than others. It is, therefore, important to rethink the body and seek images of the body that take the body more seriously. An appropriate image of the body will reduce the likelihood of sexual abuse taking place. This will be developed in the third section of this article.

\section{SEXUAL ABUSE: A FORM OF POWER ABUSE}

Sexual abuse is not only or especially a misuse of sexuality. It is, in the first instance, always a form of power abuse (Adriaenssens 2010; Ganzevoort \& Veerman 2000; Pollefeyt 1998). There is however, no consensus on this. Some researchers do not mention the link between sexual abuse and power. In addition, many researchers share the opinion that sexual abuse is above all a misuse of sexuality (Conway 2010; Grenz \& Bell 2001; Linnane 2007; Müller 2010; Trull \& Carter 2004). They are of the opinion that those who sexually abuse children have an immature sexuality, a sexuality that is insufficiently integrated in their life or personality, a lack of intimacy or a sexual ethic that fails to adequately promote human integration and flourishing. Some researchers recognize that power also plays a role in sexual abuse, but this abuse of power is, in their opinion, less important than the misuse of sexuality. By contrast, it can be argued that the abuse of power is more significant than the sexual motive, as it lies at the root of the sexual abuse and expresses itself through the body and a misuse of sexuality. The power difference makes the abuse possible.

Power is the most important factor in a discussion of sexual abuse; a critical analysis of power is thus necessary. First, power is present in different forms and shapes of sexual abuse (Ganzevoort \& Veerman 2000:39). This power is sometimes very visible. For example, when we 
talk about rape or maltreatment of the victim of sexual abuse, in general, we agree that power is at work. But, sometimes we do not recognize this power, because the use of power is very subtle. When an adult abuses a child, there is always power through the adult's position and possibilities. The adult is always more powerful than the child. In addition, the free and effective consent, which is desirable in every sexual relationship, is lacking in a sexual relationship between adult and child. The child is never in a position to truly consent, as children do not sufficiently grasp the scope and understanding of the meaning and implications of sexuality. Therefore, every sexual contact in a situation where there is an unequal relationship, and where consequently one person has more power than the other, can be called sexual abuse, because the more powerful person defines the boundaries and is responsible for respecting - or disrespecting - the limit. Due to the fact that power is not always very perceptible, it is logical that people conclude that sexual abuse has more to do with sexuality and to give full rein to one's desires. However, they overlook the fact that one first needs to be in a powerful position in order to sexually abuse someone. In an equal partner relationship, sexual abuse takes place if one of the partners does not respect the fundamental equality between partners and feels that $\mathrm{s} /$ he is more powerful than his/her partner. It is important that there is equal power in a sexual relationship between equal partners. This power should be used to respect and to please one another. The equal power of the partners also means that, in the sexual relationship, there should be free and effective consent between the partners; this is not so in the case of sexual abuse, because the perpetrator obliges or manipulates the equal victim to have sex/sexual acts with him/her. In sexual abuse, there is thus always first power, and this power is used for sexual purposes.

A second reason why we have to discuss power is that the power aspect is consistent with the feelings of the child-victim (Ganzevoort \& Veerman 2000:39). Victims feel that they are powerless and that the perpetrator is powerful. By way of sexual acts, the perpetrator may exert power over the victim, as sexual abuse affects people's integrity and intimacy (Farley 2006:163-164). The offender touches the victim in the depths of his/her being and, as a result, s/he has power over both the body and the feelings of the victim.

It is important to recognize the power that is involved in sexual abuse. Blindness to 'power' issues, in the reflection on sexual abuse, may prevent adequate reactions to sexual abuse, also within the Catholic Church. When we do not perceive that there is power at stake or when we do not reflect on our own power, or where the role is by definition strict and authoritarian and there is no reflection concerning this role, then sexual abuse is more likely to occur. In addition, the sexual abuse will, in this case, only emerge 
later. Furthermore, when society does not recognize the power at play, it cannot deal with sexual abuse appropriately. For example, the perpetrator must undergo sexual therapy, instead of the structures that confer power and lie at the root of the sexual abuse, and whereby the sexual abuse may still continue, are being addressed.

\section{SEXUAL ABUSE AND THE BODY}

When we talk about sexual abuse, we may not lose sight of the fact that power is involved. But it is also important that we take the body into account. During the sexual abuse, the perpetrator uses his/her power to violate the body of the child. The perpetrator possesses a physical superiority over the child (Demasure 2004:236-237). The child has consequently no control or power over the situation or over his/her own body. The body, especially in its sexual aspects, is one of a person's most vulnerable features where power abuse can manifest itself most clearly. The perpetrator takes away the child's freedom of choice over his/her body and uses the child's body to satisfy his/her own needs. The perpetrator not only has power over the body of the child at the time of the abuse, but the sexual abuse has a lasting impact on the body. For example, a victim of sexual abuse states,

I wish I could feel good things in my body now, but I guess that's one more thing l've had to give up because of my abuse (Holderread Heggen 2006:37).

Sexual abuse has a devastating impact on the child's body integrity. The child has been humiliated, hurt and degraded in his/her body. As a result of the sexual abuse, the child - and future adult - often has problems with his/her body. Survivors of sexual abuse at times express that they hate their body or that they want to destroy their body because of the pain they feel daily. Due to the sexual abuse, they often have a negative body and self-image (Haslbeck 2010:87; Holderread Heggen 2006:35-36).

Sexual abuse always has an impact on the body of the victim. We cannot speak of sexual abuse without taking the body into account. However, is the body also a theme in recent theological and popular literature on the sexual abuse of children by adults within family and pastoral relationships? For this article, five books are scrutinised (Dohmen 2010; Goertz \& Ulonska 2010; Müller 2010; Perner 2010a; Verschueren 2010); three books are written in Dutch and two in German; three books are more theological and two are more popular. Most of these books address the sexual abuse of children within a pastoral relationship, because they are recent books in the Dutch-German field. At first perusal, it seems that this recent literature does not attach great importance to the theme 'body'. For example, the 
word 'body' is mentioned neither in the titles, nor in the subtitles or in the table of contents, nor even in the index. After a thorough reading, it was observed that the body is occasionally mentioned. But it is certainly not a hot item in the books, despite the fact that there is, as observed, a clear link between sexual abuse and the body. The occasions on which the body is addressed can be divided into three categories, namely the body from the perspective of the perpetrator, the body from the perspective of the victim, and the body as object.

The literature sometimes mentions how the perpetrator may perceive the body of the child. We read, for example, that the perpetrator tries to justify the sexual abuse by virtue of of the child's body. According to the perpetrator, a child who does not physically resist the sexual acts of the perpetrator wants to have sex (Benda 2010:112). According to the perpetrator, there is no question of sexual abuse. We also read that the intention of the perpetrator is to destroy the sexuality of the victim through sexual abuse, both in terms of desire as well as bodily (Dohmen 2010:238). The body is also mentioned as the medium used by the perpetrator to gradually progress to sexual abuse of the child (Enders 2010:24-25). The perpetrator initially relates normally with the body and seeks, without great effort, to extend the sexual frontiers, for example by playing doctors and nurses or by doing a 'quality control'. The body is also mentioned as a reason why priests sexually abuse a child. They have had to suppress their physicality and cannot deal with it in an appropriate manner (Dohmen 2010:278). This argumentation assumes that sexual abuse is a misuse of sexuality, rather than an abuse of power, as argued in this article.

The body is also sometimes mentioned from the perspective of the victim. Victims, or rather survivors, sometimes refer to the body in their testimony of the sexual abuse. A victim mentioned that he had the feeling that he had to give his body to the perpetrator (Bilgeri 2010:171); someone else mentioned that he had the feeling that a spear had pierced through his body (Ulonska 2010a:200); another victim stated that the sexual abuse had robbed him physically (Verschueren 2010:160). In the epilogue to Verschueren's book (2010:193-202), Adriaenssens - child and adolescent psychiatrist and former chairman of the Belgian committee for handling complaints of sexual abuse in pastoral relationships - also mentions the body. He argues that the body of the victim bears the shards. For example, victims often have no appetite; the history of sexual abuse keeps them awake, and so on. However, they cannot leave their body, even though they want to do so. They survive as a result of, and despite their body. Adriaenssens believes that the recovery from sexual abuse begins by granting the body forgiveness for the vulnerability of being powerless as a youngster, in the hands of and overwhelmed by his/her perpetrator. 
When the body is mentioned in the literature, it is mostly viewed as an object, the third category. We often read that the child is regarded and treated as a possession or as a sexual object (Ulonska 2010b:71; Verschueren 2010:155). It is through sex that the perpetrator takes possession of the body of the child (Perner 2010b:5-7). The perpetrator perceives the body of the victim as a tool for his/her own needs (Goertz 2010:139). It has been mentioned that it is important to perceive the victims of sexual abuse first as subjects, and not to reduce them to the status, role or identity of the victim (Möser 2010:102). Nevertheless, we read that the treatment of victims, after they have spoken of having been sexually abused, contributes to the objectifying of the victim. Some victims in Belgium have the feeling that, once they have told their story to the authorities, they become a file, a number and a part of the statistics (Verschueren 2010:149). They have the feeling of 'I stood and watched'.

We can conclude that, in the recent theological and popular literature on sexual abuse of children by adults within family and pastoral relationships, the body is rarely a theme, yet the body and sexual abuse are closely related. When the body is mentioned, it is usually in the testimonies of victims and the body is mostly viewed as an object. We can also conclude that, if the body is mentioned, the body is mostly linked with sexuality and not so much with the power aspect. Nowhere is the power over the body of the victim mentioned. Finally, we can conclude that there was no real (theological) consideration of the body in the studied literature. Yet, this was the case in feminist literature of, for example, Gudorf (1995), Isherwood and Stuart (1998), Ross (1998) and the Belgian theologians Decoene and Depoorter (2007).

\section{AN APPROPRIATE PERCEPTION OF THE BODY}

The way in which the body is perceived may influence whether or not sexual abuse takes place. In the studied literature, for example, we observe that the perpetrator generally views the body as an object, a toy, a consumer article. In this way, the perpetrator may feel that $\mathrm{s} / \mathrm{he}$ is not abusing a child, but only 'playing' with the body. The perpetrator has a dualistic approach to reality and disconnects the body and the soul. By seeing the body as pure material, sexual abuse presents no problem for the perpetrator. The body is simply something you own, and with which you can do whatever you want.

The victims of sexual abuse also use this objectification and dualisation of body and soul in the process of dissociation. A victim testifies: 
The pain to my little body was excruciating when he abused me. The only way I survived was to learn to turn off my feelings (Holderhead Heggen 2006:37).

Another victim notes: "Since they were usually unable physically to escape the abuse, they learned to escape mentally" (Holderhead Heggen 2006:38). At the moment of sexual abuse, the victims mostly perceived and experienced their body as pure, because they felt that only their body was hurt and not their person. A victim states, for example:

I was too little to stop the abuse and protect my body. But I was determined he wouldn't hurt the real me. So I learned how to float out of my body where he couldn't get me (Holderhead Heggen 2006:38).

The objectification of the body and a dualist approach, where the body is perceived as being unrelated to the soul, can be explained on the basis of the Christian tradition, on the one hand, and on contemporary society, on the other.

In the Christian tradition, one can find a negative association with, and a negative appreciation of the body. Through the entire history of Christianity, starting with Paul, the body is viewed as inferior, negative, sinful and pernicious (Decoene \& Depoorter 2006:70-72). The soul is considered higher than the body which, in turn, is perceived as an enemy that must be kept under control. The Hellenic thought that places the spiritual above the material influences this dualistic thought of body and soul in the Christian tradition. During sexual abuse, both the perpetrator and the victim use this traditional separation of body and soul as well as the objectification of the body. It provides support to the victims who undergo sexual abuse and offers the perpetrators a way to easily move into sexual abuse. The question can be asked as to whether this negative, dualistic view of the body in the Christian tradition could encourage and legitimate sexual abuse.

In addition, in our (Western) society, the image of the body contributes to incidents of sexual abuse. The perfect body takes an important place in our (Western) society (Dillen 2007:157). The body is generally perceived in an aesthetic and functional manner and is usually considered an object (Burggraeve 2003:380). On account of this liberal vision of the body, there is a risk that people assume that they may touch the body of others. This vision of the body may also often encourage the victims of sexual abuse to blame themselves for sexual abuse. They believe that it is their fault, because they have allowed their bodies to be seen. The view on sex in contemporary Western society also plays a role in sexual abuse. Due to 
the sexual revolution, people deal with sexuality more freely, and sexuality is related to pleasure. Perpetrators of sexual abuse view this changing ethos as a permit to give full rein to their sexual needs. They also assume that their victims like it.

In both the present society and in the Christian tradition, a dualistic approach and an objectification of the body may encourage sexual abuse. This challenges us to find an appropriate image of the body that may reduce the likelihood of sexual abuse, although more action is essential in order to prevent sexual abuse. For this purpose, we can make use of the insights of feminist theology. Feminist theology opposes the dualistic thinking of the body and soul and the objectification of the body. It is argued that the body may no longer be perceived as something that one 'has', but as something that one 'is'. This thought also occurs in Merleau-Ponty's phenomenology (1945:175). He states that the body is not an object, something that we have, but a subject, something that we are. According to him, the body is a lived body; it is a matter that we are. The body is more than flesh and bones; it also encloses our experiences, thoughts and emotions. Body and soul are thus 'one' in the feminist view of the body. The soul penetrates the body; the body is the 'soul' and makes the soul possible (Burggraeve 2003:383). This is the reason why some feminist theologians use the term 'bodyself' (Gudorf 1995:160; Heyward 1989:40). Unlike a dualistic vision, the holistic vision, where body and soul are no longer separated from each other, is less likely to lead to sexual abuse. To 'be' a body offers more resistance to sexual abuse than to 'have' a body. To 'have' a body is more connected with the power discourse, and this gives the impression that one has to possess power over both one's own body and the body of another and that one may do whatever one wishes with the body of another. By contrast, to 'be' a body means that a body belongs to a person and that no one else may have power over the body of that person. There is a need for a subjectification of the body, rather than an objectification. This view can be supported from a Christian perspective. Although there is some hostility to the body in the Christian faith, many elements in the faith of the Christian tradition can generate a positive view of the body (Dillen 2007:159). Such reflections of a positive view of the body are to be found in, for example, the theology of the incarnation, the bodily resurrection and the Eucharist. The body is central in the Christian faith and may be viewed as the place where God can be found. This positive, holistic approach of the body and the view that one 'is' a body where God can be found, will reduce the likelihood of sexual abuse. 


\section{CONCLUSION}

Sexual abuse is always a form of power abuse. The relationship between the perpetrator and the child-victim always involves power. The perpetrator's power reveals itself in sexual acts. We have to be aware of this aspect of power in sexual abuse in order to deal with it in an appropriate manner. In addition, there is always the (lasting) power of the perpetrator over the body of the victim. The body is an important theme in discussions of sexual abuse, because sexual abuse has a huge impact on the body of the victim, and the way in which the perpetrator perceives the body can encourage $\mathrm{him} / \mathrm{her}$ to sexually abuse someone. A dualisation and an objectification of the body may encourage sexual abuse, whereas a holistic view and the perception that we 'are' a body and do not 'have' a body, and that the body is the place where God can be found reduce the likelihood of sexual abuse. Although the perception of the body may influence sexual abuse, the body is not an important theme in recent theological and popular literature on sexual abuse of children by adults within family and pastoral relationships.

\section{BIBLIOGRAPHY}

Adriaenssens, P.

2010. Herstel voor onverwerkbaar verleden (persconferentie n.a.v ontslag Roger Vangheluwe 2010). [Online.] Retrieved from: http://www.kerknet.be/microsite/ commissiemisbruik/content.php?ID=13393 [2013, 19 February].

BENDA, E.

2010. Machtgelüste. In: R.A. Perner (Hrsg.), Missbrauch. Kirche - Täter - Opfer (Berlin: LIT), pp. 106-117.

BILGERI, R.

2010. Denn sie wissen nicht was sie tun ... Oder wissen sie es doch? In: R.A. Perner (Hrsg.), Missbrauch. Kirche - Täter - Opfer (Berlin: LIT), pp. 149-186.

Borgman, E. \& Torfs, R. (REDS.)

2011. Grensoverschrijdingen geduid. Over seksueel misbruik in katholieke instellingen. Nijmegen: Valkhof Pers.

Burggraeve, $R$.

2003. Het lichaam van de liefde. Over samenwonen of huwen en gezin. Collationes 33:363-391.

Conway, E.

2010. Seksueel geweld tegen minderjarigen. De crisis in de lerse kerk en een schets van de theologische agenda. Tijdschrift voor Theologie 50(2):184-204. 
Decoene, A. \& Depoorter, A.

2007. Niet de dood is het probleem, maar het doden. Feminisme, lichamelijkheid en theologie. In: L. Boeve \& A. Decoene (reds.), Wat mogen we hopen? Perspectieven op de verrijzenis van het lichaam (Antwerpen: Halewijn), pp. 67-78.

Deetman, W., Draijer, N., Kalbfleisch, P., Merckelbach, H., Monteiro, M. \& De VRIES, G.

2011. Seksueel misbruik van minderjarigen in de Rooms-Katholieke kerk. Uitgebreide versie, Deel 1 Het onderzoek. Amsterdam: Balans.

Demasure, $\mathrm{K}$.

2004. Verdwaald tussen liefde, macht en schuld. Een hermeneutisch model voor pastorale begeleiding van dader en slachtoffer bij seksueel misbruik van kinderen. Leuven: Peeters.

Dillen, A.

2007. De kwetsbaarheid van het lichaam. Feministisch-theologische reflecties. Tijdschrift voor Theologie 47(2):155-173.

De BISSChoppen en Hogere oversten VAN België 2012. Verborgen verdriet. Naar een globale aanpak van seksueel misbruik in de kerk. Brussel: Licap.

DOKECKI, P.R.

2004. The clergy sexual abuse crisis. Reform and renewal in the Catholic community. Washington, DC: Georgetown University Press.

DOHMEN, J.

2010. Vrome zondaars. Misbruik in de Rooms-Katholieke Kerk. Rotterdam: NRC boeken.

ENDERS, U.

2010. Sexueller Missbrauch in Institutionen. In: S. Goertz \& H. Ulonska (Hrsg.), Sexuelle Gewalt. Fragen an Kirche und Theologie (Berlin: LIT), pp.17-44.

FARLEY, M.A.

2006. Just love. A framework for Christian sexual ethics. New York: Continuum.

Ganzevoort, R., Hegger, A., De Groot-Kopetzky, B., Kips, M., De Smedt, P.,

De Fruyt, K., Rector, G. \& Van Beek, l. (reds.)

2013. Geschonden vertrouwen. Seksueel misbruik in een religieuze context. Tilburg: KSGV.

Ganzevoort, R. \& Veerman, A.L.

2000. Geschonden lichaam. Pastorale gids voor gemeenten die geconfronteerd worden met seksueel geweld. Zoetemeer: Boekencentrum.

GoerTz, S.

2010. Sexuelle Gewalt als individuelle Sünde gegen das sechste Gebot! In: S. Goertz \& H. Ulonska (Hrsg.), Sexuelle Gewalt. Fragen an Kirche und Theologie (Berlin: LIT), pp. 127-146. 
Grenz, S.J. \& Bell, R.D.

2001. Betrayal of trust. Confronting and preventing clergy sexual misconduct. Grand Rapids, MI: Baker Books.

GudORF, C.E.

1995. Body, sex, and pleasure. Reconstructing Christian sexual ethics. Cleveland, $\mathrm{OH}$ : The Pilgrim Press.

HASLBECK, B.

2010. Der Stachel der Opfer. Zum kirchlichen Umgang mit Opfern sexualisierter Gewalt. In: S. Goertz \& H. Ulonska (Hrsg.), Sexuelle Gewalt. Fragen an Kirche und Theologie (Berlin: LIT), pp. 83-91.

HeYward, C.

1989. Touching our strength. The erotic as power and the love of god. San Francisco, CA: HarperSanFrancisco.

Holderread Heggen, C.

2006. Sexual abuse in Christian homes and churches. Eugene, OR: Wipf \& Stock Publishers.

ISHERWOOD, L. \& STUART, E. 1998. Introducing body theology. Sheffield: Sheffield Academic Press.

KeEnan, M.

2012. Child sexual abuse and the Catholic Church. Gender, power, and organizational culture. Oxford: Oxford University Press.

Kiessling, K. (HRSG.)

2011. Sexueller Missbrauch. Fakten - Folgen - Fragen. Ostfildern: Grünewald.

LINNANE, B.F.

2007. The sexual abuse scandal in the Catholic Church. Implications for sexual ethics. In: M.A. Ryan \& B.F. Linnane (eds.), Just and true love. Feminism at the frontiers of theological ethics. Essays in honor of Margaret Farley (Notre Dame: University of Notre Dame Press), pp. 273-302.

Merleau-Ponty, M.

1945. Phénoménologie de la perception. Paris: Librairie Gallimard.

MöseR, M.K. 2010. Auf das Opfer darf keiner sich berufen. In: S. Goertz \& H. Ulonska (Hrsg.), Sexuelle Gewalt. Fragen an Kirche und Theologie (Berlin: LIT), pp. 93-104.

MülLER, W. 2010. Verzwegen wonden. Seksueel misbruik in de Katholieke Kerk erkennen en verhinderen. Averbode: Kok.

Perner, R.A. 2010b. Mühlsteine. Die Produktion von Abhängigkeit. In: R.A. Perner (Hrsg.), Missbrauch. Kirch - Täter - Opfer (Berlin: LIT), pp. 4-18. 
Pollefeyt, D.

1998. Intimiteit in de pastoraal. Ethische kanttekeningen bij het gebruik van macht binnen de pastorale begeleiding. Collationes 28:227-245.

Ross, S.A.

1998. Extravagant affections. A feminist sacramental theology. New York: Continuum.

Scicluna, C.J., Zollner, H. \& Ayotte D.J. (eds.)

2012. Towards healing and renewal. The 2012 Symposium on the Sexual Abuse of Minors, held at the Pontifical Gregorian University. Mahwah, NJ: Paulist Press.

SHOOTER, S.

2012. How survivors of abuse relate to God. The authentic spirituality of the annihilated soul. Farnham: Ashgate.

TruLL, J.E. \& CARTER, J.E.

2004. Ministerial ethics. Moral formation for church leaders. Grand Rapids, MI: Baker Academic.

ULONSKA, H.

2010a. Selbstreflexionen im Umgang mit sexualisierter Gewalt. In: S. Goertz \& H. Ulonska (Hrsg.), Sexuelle Gewalt. Fragen an Kirche und Theologie (Berlin: LIT), pp. 193-204.

2010b. Sexualisierte Gewalt im Kontext kritischer Priester- und Pfarrerforschung. In: S. Goertz \& H. Ulonska (Hrsg.), Sexuelle Gewalt. Fragen an Kirche und Theologie (Berlin: LIT), pp. 67-81.

VERSCHUEREN, R.

2010. Morgen is van mij. Een antwoord op seksueel misbruik in de kerk. Tielt: Lannoo.

Keywords

Sexual abuse

Power

Body
Trefwoorde

Seksuele misbruik

Mag

Liggaam 